\title{
Dearomative Cycloadditions Catalyzed by Palladium
}

$$
\text { (0.1 mmol) }
$$<smiles>[R]C1C(=C)CC2([N+](=O)[O-])c3cccnc3C=CC12</smiles>

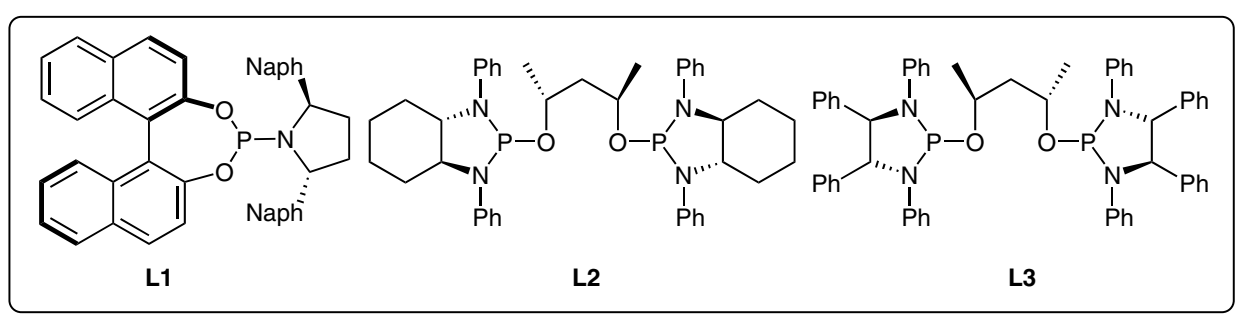

\section{Examples:}<smiles>C=C1CC2C=Cc3ncccc3C2([N+](=O)[O-])C1</smiles>

$98 \%$ yield, $35 \%$ ee with $5 \mathrm{~mol} \% \mathrm{Pd}(\mathrm{dba})_{2}$ and $10 \mathrm{~mol} \% \mathrm{~L} 1$ at $50^{\circ} \mathrm{C}$<smiles>C=C1CC2([N+](=O)[O-])c3cccnc3C=CC2C1C#CC(C)(C)C</smiles>

$77 \%$ yield, $95 \%$ ee
dr $=4: 1$ with $\mathbf{L 2}$<smiles>C=C1CC([N+](=O)[O-])([N+](=O)[O-])C2C=CN(Oc3ccccc3)C(C#CC)[C@@H]12</smiles>

$55 \%$ yield, $90 \%$ ee
dr $=5: 1$ $\mathrm{dr}=5: 1$

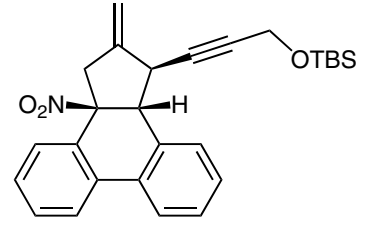

$63 \%$ yield, $85 \%$ ee $75 \%$ yield, $85 \%$ ee $\mathrm{dr}=3: 1 \quad \mathrm{dr}=5: 1$ with L2
Category

Metal-Catalyzed

Asymmetric

Synthesis and

Stereoselective

Reactions

\section{Key words}

palladium

nitroarenes

trimethylenemethanes

[3+2] cycloaddition
Significance: The authors describe a palladiumcatalyzed enantioselective dearomative trimethylenemethane (TMM) [3+2] cycloaddition with three nitroarenes. Chiral phosphoramidite or diamidophosphites were utilized to induce moderate to high levels of enantioselectivities along with high chemical yields. The key significance of this work is the selective tuning of the reactivity and enantioselectivity of the catalyst system, which enables exclusive formation of the dearomatized products for an intermolecular cycloaddition in high enantioselectivities.
Comment: The current catalytic system is unable to induce high levels of enantioselectivities for the unsubstituted TMM donor in contrast to the alkynyl-substituted TMM donor. It was proposed that the alkynyl substituent bonds tightly to the $\beta$-carbon of the nitroarene and creates more steric bulk, which enables a higher degree of differentiation between the two prochiral phases in the transition state. 